\title{
THE
}

\section{Site Fidelity, Philopatry, and Survival of Promiscuous Saltmarsh Sharp-Tailed Sparrows in Rhode Island}

\author{
Deborah A. DiQuinzio \\ University of Rhode Island \\ Peter W. C. Paton \\ University of Rhode Island, ppaton@uri.edu \\ William R. Eddleman
}

Follow this and additional works at: https://digitalcommons.uri.edu/nrs_facpubs

Terms of Use

All rights reserved under copyright.

\section{Citation/Publisher Attribution}

DiQuinzio, D., Paton, P. W.C., \& Eddleman, W. R. (2001). Site fidelity, philopatry, and survival of promiscuous Saltmarsh Sharp-tailed Sparrows in Rhode Island. The Auk, 118(4), 888-899. doi: /10.1642/ 0004-8038(2001)118[0888:sfpaso]2.0.co;2 Available at: http://dx.doi.org/10.1642/0004-8038(2001)118[0888:sfpaso]2.0.co;2

This Article is brought to you for free and open access by the Natural Resources Science at DigitalCommons@URI. It has been accepted for inclusion in Natural Resources Science Faculty Publications by an authorized administrator of DigitalCommons@URI. For more information, please contact digitalcommons-group@uri.edu. 


\title{
SITE FIDELITY, PHILOPATRY, AND SURVIVAL OF PROMISCUOUS SALTMARSH SHARP-TAILED SPARROWS IN RHODE ISLAND
}

\author{
Author(s): Deborah A. DiQuinzio, Peter W. C. Paton, William R. Eddleman \\ Source: The Auk, 118(4):888-899. 2001. \\ Published By: The American Ornithologists' Union \\ DOI: http://dx.doi.org/10.1642/0004-8038(2001)118[0888:SFPASO]2.0.CO;2 \\ URL: http://www.bioone.org/doi/full/10.1642/0004-8038\%282001\%29118\%5B0888\%3ASFPASO \\ $\% 5 \mathrm{D} 2.0 . \mathrm{CO} \% 3 \mathrm{~B} 2$
}

BioOne (www.bioone.org) is a nonprofit, online aggregation of core research in the biological, ecological, and environmental sciences. BioOne provides a sustainable online platform for over 170 journals and books published by nonprofit societies, associations, museums, institutions, and presses.

Your use of this PDF, the BioOne Web site, and all posted and associated content indicates your acceptance of BioOne's Terms of Use, available at www.bioone.org/page/terms_of_use.

Usage of BioOne content is strictly limited to personal, educational, and non-commercial use. Commercial inquiries or rights and permissions requests should be directed to the individual publisher as copyright holder. 


\title{
SITE FIDELITY, PHILOPATRY, AND SURVIVAL OF PROMISCUOUS SALTMARSH SHARP-TAILED SPARROWS IN RHODE ISLAND
}

\author{
Deborah A. DiQuinzio, ${ }^{1}$ Peter W. C. Paton, and William R. Eddleman ${ }^{2}$ \\ Department of Natural Resources Science, University of Rhode Island, Kingston, Rhode Island 02881, USA
}

\begin{abstract}
We investigated site fidelity and apparent survival in a promiscuous population of Saltmarsh Sharp-tailed Sparrows (Ammodramus caudacutus) in southern Rhode Island. Based on capture-recapture histories of 446 color-banded sparrows studied from 1993 to 1998 at our primary study site, Galilee, we observed significant variation in apparent survival rates among years, but not between sexes. Return rates of adult males (37.6\%) and females $(35.6 \%)$ were not significantly different during any year. Juveniles exhibited high return rates, ranging from 0 to $44 \%$, with males (61\% of returns) more likely to return than females (35\%). In addition, we monitored movements of 404 color-banded sparrows at nine satellite marshes in 1997 and 1998, which supported our findings at Galilee and documented intermarsh movements by $10 \%$ of all banded birds. Lack of gender-bias in adult dispersal and strong natal philopatry of sparrows in Rhode Island occurs regularly among passerines possessing a variety of mating systems. Despite emancipation from parental and resource defense duties, adult male Saltmarsh Sharp-tailed Sparrows exhibited apparent survival rates similar to adult females. Availability of high-quality breeding habitat, which is patchy and saturated, may be the most important factor limiting dispersal for Saltmarsh Sharptailed Sparrows in Rhode Island. Received 5 January 2000, accepted 24 April 2001.
\end{abstract}

SALTMARSH SHARP-TAILED SPARROWS (Ammodramus caudacutus) (hereafter "sparrows") are one of the few passerines in North America with a promiscuous mating system, also documented as scramble competition polygyny (Post and Greenlaw 1982, Ehrlich et al. 1988). No pair bonds or defendable territories are established and copulation frequently occurs through forced mating (Post and Greenlaw 1982). Current theory predicts specific gender biases in dispersal is related to evolution of mating systems (Greenwood 1980, Clarke et al. 1997). Greenwood (1980) hypothesized a female-bias in dispersal was pronounced among birds because resource defense by monogamous males determines mate acquisition, whereas mammals generally exhibit male-biased dispersal in polygamous mating systems dominated by mate defense. Because sparrows do not exhibit mateor resource-defense behaviors, we would expect gender equality in dispersal. Because female sparrows are solely responsible for selecting nest sites and rearing young, we might expect

\footnotetext{
${ }^{1}$ Present address: National Park Service, Boston Support Office, 15 State Street, Boston, Massachusetts 02109, USA. E-mail: deb_diquinzio@nps.gov

${ }^{2}$ Present address: Department of Biology, Southeast Missouri State University, Cape Girardeau, Missouri 63701, USA.
}

survival rates to differ from emancipated males (Clarke et al. 1997). On the basis of previous studies of promiscuous passerines, we would also predict high female-biased natal dispersal (Post and Greenlaw 1982, Russell and Rowley 1993, Weatherhead and Forbes 1994). As an alternative hypothesis, dispersal patterns may be a function of availability of high-quality habitat. Ninety-percent of the sparrow's breeding range occurs in the Northeast, where much salt-marsh habitat has been lost or degraded (Bourn and Cottam 1950, Tiner 1984, Rozsa 1995). Both sexes may benefit in returning to areas where food resources are familiar and predation rates are low (Oring and Sayler 1992). We tested those predictions by investigating site fidelity, philopatry, and survival of a migratory population of sparrows in Rhode Island. We determined annual and cumulative return rates (Custer and Pitelka 1977) to compare our results to past research and used modern capture-recapture models to produce apparent survival estimates (Lebreton et al. 1992). We also described movement of sparrows among study marshes.

\section{Methods}

Data collection.-We conducted fieldwork in 10 estuarine, emergent wetlands in southern Rhode Island. Our primary study site was Galilee Bird Sanc- 


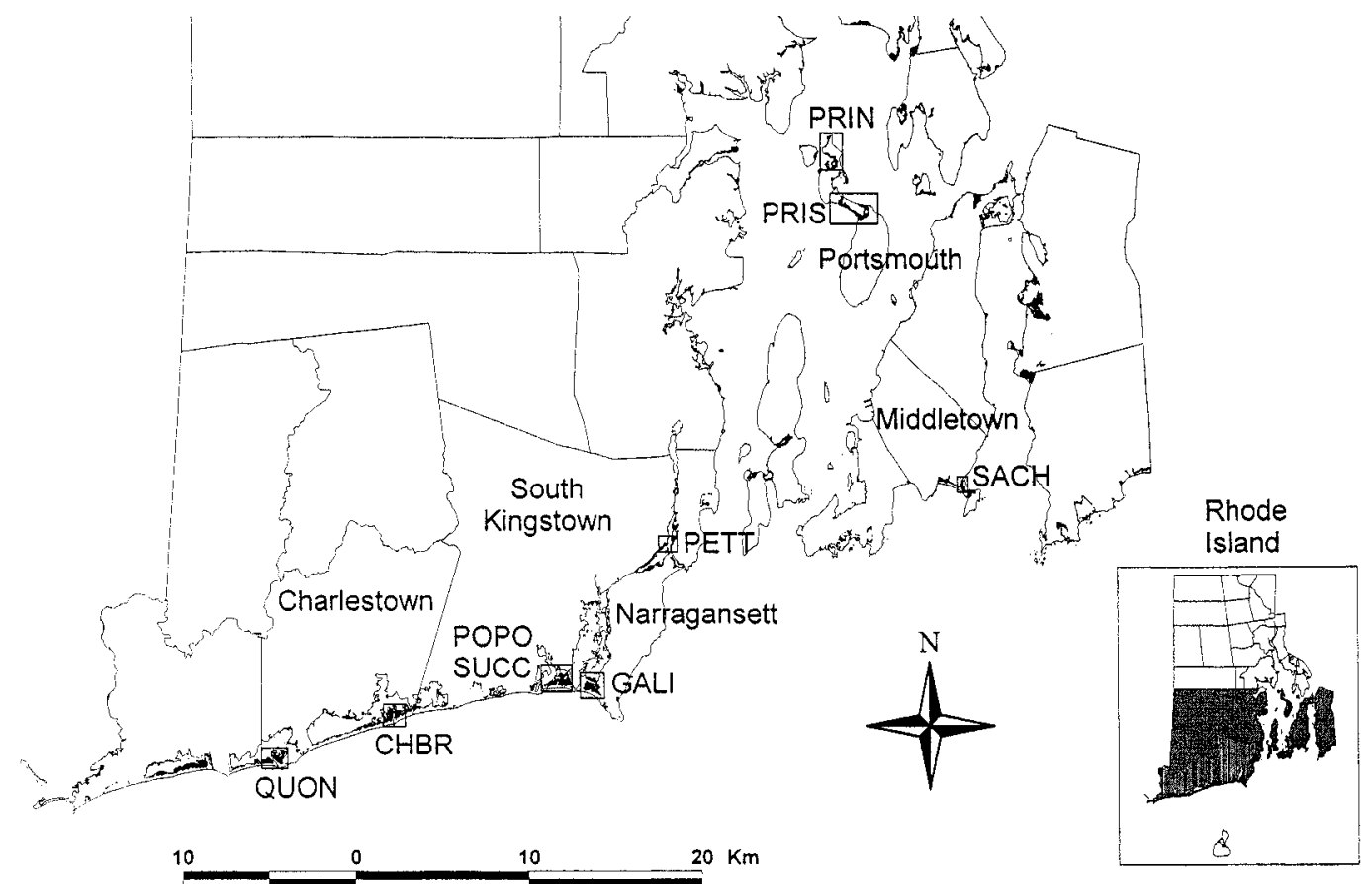

FIG. 1. Location of Saltmarsh Sharp-tailed Sparrow study sites in southern Rhode Island. QUON = Quonochontaug Pond, $\mathrm{CHBR}=$ Charlestown Breachway, $\mathrm{POPO}=$ Potter's Pond, $\mathrm{SUCC}=$ Succotash Marsh, GALI $=$ Galilee Marsh, PETT $=$ Pettaquamscutt River, $\mathrm{SACH}=$ Sachuest National Wildlife Refuge, PRIS $=$ Nag Creek Marshes on Prudence Island, PRIN = Coggeshall and North End marshes on Prudence Island.

tuary (hereafter "Galilee," 16.5 ha; 4583579 N, 290793 E; area sampled and Universal Transverse Mercator [UTM] coordinates). We also sampled nine satellite marshes: Pettaquamscutt River (9.5 ha; 4592008 N, 295335 E); Quonochontaug Pond (9.5 ha; 4579192 N, 272637 E); Charlestown Breachway (8.8 ha; 4582002 N, 279432 E); Potter's Pond (7.6 ha; 4583727 N, 288491 E); Succotash Marsh (6.9 ha; 4583751 N, 288923 E); Sachuest National Wildlife Refuge (5.8 ha; 4595214 N, 312166 E); Nag Creek at the south end of the Narragansett Bay National Estuarine Research Reserve (NBNERR) on Prudence Island (20.0 ha; 306276 N, $4610608 \mathrm{E})$; and Coggeshall (8.5 ha; $304892 \mathrm{~N}, 4613766 \mathrm{E}$ ) and North End (3.5 ha; 304556 N, 4614973 E) marshes of the NBNERR on northern Prudence Island (Fig. 1). We obtained UTM coordinates and the total area sampled from 1995 Natural Resources Conservation Service/U.S. Geological Survey digital orthophotographs and map data (NAD 27) from Rhode Island Geographic Information System (RIGIS) (August et al. 1995). Dominant vegetation types across study sites were salt meadow (Spartina patens, Juncus gerardii, and Distichlis spicata), salt-marsh cordgrass (Spartina alterniflora), common reed (Phragmites australis), and hightide bush (Iva frutescens) (Bertness 1992). Galilee was dominated by extensive stands of common reed, due to a restricted tidal regime. During the fall of 1997, culverts were installed to increase tidal flow and restore the area to a marsh dominated by salt meadow and salt-marsh cordgrass (DiQuinzio 1999).

We captured sparrows in mist nets placed near vegetation or creek edges, observed nests, and activity centers. We operated 5 to $8,12 \times 2.6 \mathrm{~m}, 30 \mathrm{~mm}$ mesh nets for $\sim 5 \mathrm{~h}$ each day, beginning at sunrise. We maximized coverage of marshes by changing the location of nets at each site visit. Galilee marsh was visited 30-45 days annually from 1993 to 1998, whereas satellite marshes were surveyed 7-21 days in both 1997 and 1998 (DiQuinzio 1999). We calculated accumulation curves on the basis of the first capture or sighting of an adult male and female sparrow for 1997 and 1998 breeding seasons. Accumulation curves indicated that number of sparrows at a marsh was adequately sampled with 7 to 10 surveys by the end of July (DiQuinzio 1999). Sparrows return to Rhode Island marshes in mid-May and depart in early September to mid-October (DeRagon 1988). We captured sparrows from late May to late August during 1993 to 1998 at Galilee; 1996 to 1998 at Quonochontaug, Charlestown, and Potter's ponds; and 1997 to 1998 at Succotash, Pettaquamscutt, Sachuest, and Prudence Island marshes. Chase et al. (1997) defined "transients" as migrants, floaters, or nonterritorial 
adults. Male Saltmarsh Sharp-tailed Sparrows do not defend territories and constantly move within and among marshes (Greenlaw and Rising 1994, DiQuinzio 1999); therefore, prior definitions are not relevant and we defined transients as migrants passing through the study area. We scheduled fieldwork outside the migration period to minimize inclusion of transients.

We banded sparrows with a unique combination of three plastic color-bands and a federal aluminum band. We could not identify gender by plumage; therefore, we determined sex for $96 \%$ of adults (after hatching year) on the basis of the presence of an enlarged cloacal protuberance (males) or a brood patch (females) (Sibley 1996, Pyle 1997). We banded juvenile (hatching-year) sparrows in the nest at 5-9 days of age or with the use of mist nets once fledged. We distinguished juvenile from adult birds by plumage (Sibley 1996) and size differences (in wing and tail length and weight). We recorded color-band combinations for all individuals sighted during the breeding seasons 1996 to 1998, allowing us to determine presence of birds not captured in nets.

Survival and return-rate analyses. - We used the program SURGE (Survival Generalized Model; Lebreton et al. 1992) to calculate maximum-likelihood estimates of survival and recapture probabilities by fitting modified Cormack-Jolly-Seber models (Jolly 1965, Seber 1965) for six years of banding data from Galilee. We based annual survival probabilities on the entire capture history of each bird, taking into account birds not recaptured in a given year. "Recapture probability" was the probability that a bird was captured if it was present in the study area. We performed goodness-of-fit tests 2 and 3 using the program RELEASE (Burnham et al. 1987) to explore heterogeneity in recapture and survival probabilities. SURGE models tested time, age, and gender variation in survival and recapture probabilities, with time-gender and time-age interactions. We modeled user-defined age classes for sparrows first captured as juveniles. The best-fitting models were indicated by a low Akaike's Information Criterion (AIC) value, calculated as sum of model deviance and twice the number of parameters. Models having similarly low AIC values were compared with likelihood-ratio tests (chi-square) to select one best-fitting model (Cooch et al. 1996). We determined individual significance of sex, age, and time on survival and recapture estimates with likelihood-ratio tests (chisquare) that compared the AIC-selected model containing the test variable against the model without the test variable. We considered models to be significantly different if $P \leq 0.05$. Birds of unknown age, gender, or both were removed from corresponding analyses.

We used capture and sighting data from all study sites during 1996-1998 and from Galilee during 1993-1998 to directly estimate annual return rates.
With exception of Galilee, we pooled data for marshes that were $<1 \mathrm{~km}$ apart: Potter's Pond and Succotash, and Coggeshall and North End. We calculated annual return rates as percentage of birds recaptured or resighted from the total number of birds present the previous breeding season. Estimates were noncumulative and based on number of birds returning only the following year. We compared age, gender, study site, and annual differences in return rates using a likelihood ratio test (chi-square), with significance at $P \leq 0.05$ (SAS Institute 1988). We also calculated cumulative return rates for adults captured at Galilee from 1993 to 1998. We used methods described by Custer and Pitelka (1977) to determine cumulative return rates comparable to previous research by Post and Greenlaw (1982). We removed birds of unknown age and sex from analyses. Lastly, we recorded local movement among study sites by age and gender, and obtained distances using RIGIS map data (August et al. 1995) and ARCVIEW software (Environmental Systems Research Institute 1998).

Recent capture-recapture studies have stressed the importance of removing transients from survival and return-rate analyses, because they tend to depress estimates (Chase et al. 1997, Loery et al. 1997, Pradel et al. 1997). When we excluded initial capture year to produce unbiased estimates for residents (Custer and Pitelka 1977, Pradel et al. 1997), cumulative return rates at Galilee were not significantly different than those for all captures of males $(33.3 \%$, $n=19$ vs. $37.5 \%, n=57 ; P=0.27)$ and females (26.5\%, $n=9$ vs. $34.3 \%, n=34 ; P=0.08)$. Program RELEASE (Test 3.SR; Burnham et al. 1987), which is sensitive to differences in survival between newly marked and previously marked individuals (Pradel et al. 1997), indicated no significant difference for adult sparrows $\left(\chi^{2}=2.66, \mathrm{df}=4, P=0.62\right)$. Those results suggest that we captured few transient sparrows and minimized associated bias. We considered survival and return rates minimum estimates due to inability to differentiate mortality from permanent dispersal, which has been termed "apparent survival" (Lebreton et al. 1992, Chase et al. 1997). High annual fluctuation and limited recapture of juvenile sparrows should be taken into account when interpreting survival and return-rate estimates.

\section{RESUlts}

Survival and recapture estimates.-A total of 446 Saltmarsh Sharp-tailed Sparrows were banded from 1993 to 1997 at Galilee: 95 adult males, 65 adult females, 15 unknown adults, and 271 juveniles (Table 1). Goodness-of-fit, Test 2 from program RELEASE provided inconclusive results regarding variation in recapture probability over time; however, Test 3 pro- 
TABLE 1. Capture-recapture histories for Saltmarsh Sharp-tailed Sparrows at Galilee Marsh, Rhode Island, 1993 to 1998. Number of sparrows captured and released annually and exhibiting each capture history are given.

\begin{tabular}{lrrrrr}
\hline \hline \multirow{3}{*}{$\begin{array}{l}\text { Capture } \\
\text { history }\end{array}$} & \multicolumn{3}{c}{ Adults } & & \\
\cline { 2 - 4 } & Female & Male & Unknown & Juveniles & Total \\
\hline 100000 & 13 & 16 & 4 & 65 & 98 \\
110000 & 11 & 14 & 0 & 2 & 27 \\
111000 & 3 & 5 & 0 & 0 & 8 \\
110100 & 1 & 0 & 0 & 0 & 1 \\
100100 & 0 & 1 & 0 & 0 & 1 \\
111100 & 1 & 2 & 0 & 0 & 3 \\
111110 & 0 & 2 & 0 & 0 & 2 \\
010000 & 14 & 13 & 3 & 111 & 141 \\
011000 & 5 & 5 & 0 & 16 & 26 \\
011100 & 0 & 0 & 0 & 5 & 5 \\
011110 & 0 & 0 & 0 & 1 & 1 \\
010111 & 1 & 1 & 0 & 0 & 2 \\
001000 & 4 & 6 & 3 & 37 & 50 \\
001100 & 0 & 2 & 0 & 0 & 2 \\
000100 & 4 & 10 & 2 & 9 & 25 \\
000110 & 0 & 3 & 0 & 5 & 8 \\
000111 & 0 & 0 & 0 & 2 & 2 \\
000010 & 4 & 10 & 3 & 18 & 35 \\
000011 & 4 & 5 & 0 & 0 & 9 \\
Total & 65 & 95 & 15 & 271 & 446 \\
\hline
\end{tabular}

${ }^{a}$ Capture $=1$, no capture $=0$.

vided evidence of significant variation in survival probability over time (all birds, $\chi^{2}=$ 21.12, $\mathrm{df}=9, P=0.012$; adults, $\chi^{2}=3.24$, $\mathrm{df}=$ $5, P=0.66$; juveniles, $\chi^{2}=17.89$, $\mathrm{df}=4, P=$ $0.001)$.

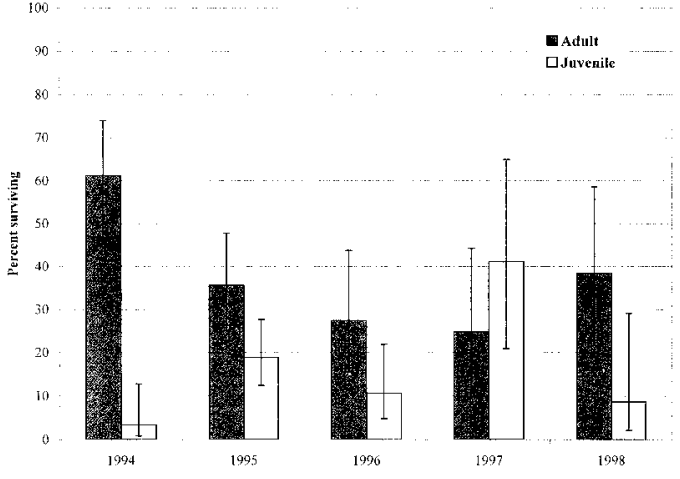

FIG. 2. Annual apparent survival rates (model $S_{\text {at }}$ R) for adult and juvenile Saltmarsh Sharp-tailed Sparrows at Galilee Marsh during 1993-1998. Refer to Table 1 for sample sizes.

Apparent survival of sparrows banded as adults at Galilee varied annually, with no difference between males and females. The bestfit model, $S_{t} R$, provided a constant recapture probability of $82.4 \%$ (95\% confidence interval [CI]: 64.8-92.3\%) and annual survival for adults (males and females pooled) ranging from 26.6 to $65.8 \%$ (Table 2 and Fig. 2). High recapture probability suggests we were successful in capturing most adult birds present. Individual likelihood-ratio tests confirmed survival probabilities did not vary significantly between male and female adults (model $S_{s t} R$

TABLE 2. Akaike's Information Criterion (AIC) scores for some annual survival and recapture models investigated with the program SURGE for adult male and female Saltmarsh Sharp-tailed Sparrows data collected in Rhode Island, 1993-1998.

\begin{tabular}{|c|c|c|c|c|}
\hline Modela $^{a}$ & $\begin{array}{c}\text { No. of } \\
\text { parameters }\end{array}$ & $\mathrm{DEV}^{\mathrm{b}}$ & $\mathrm{AIC}$ & Comparison \\
\hline$S_{s t} R_{s t}$ & 20 & 323.90 & 359.90 & Sex-time interaction on $\mathrm{S}$ and $\mathrm{R}$ \\
\hline$S_{s t} R_{s}$ & 12 & 333.59 & 357.59 & Sex-time interaction on $S$, sex differences in $R$ \\
\hline $\mathrm{S}_{\mathrm{st}}^{\mathrm{st}} \mathrm{R}_{\mathrm{a}}$ & 15 & 326.20 & 356.20 & Sex-time interaction on $\mathrm{S}$, time effect on $\mathrm{R}$ \\
\hline$S_{s t} R$ & 11 & 333.82 & 355.82 & Sex-time interaction on $S$, constant $R$ \\
\hline$S_{s} R_{s t}$ & 12 & 341.42 & 365.42 & Sex differences in $S$, sex-time interaction on $R$ \\
\hline$S_{t} R_{s t}$ & 15 & 326.94 & 354.94 & Time effect on $\mathrm{S}$, sex-time interaction on $\mathrm{R}$ \\
\hline$S R_{s t}$ & 11 & 341.58 & 363.58 & Constant $\mathrm{S}$, sex-time interaction on $\mathrm{R}$ \\
\hline $\mathrm{S}_{\mathrm{s}} \mathrm{R}_{\mathrm{t}}$ & 7 & 346.52 & 360.52 & Sex differences in $S$, time effect on $R$ \\
\hline$S_{t} R_{s}$ & 7 & 337.76 & 351.76 & Time effect on $S$, sex differences in $R$ \\
\hline$S_{t} R_{t}$ & 10 & 330.33 & 348.33 & Time effect on $\mathrm{S}$ and $\mathrm{R}$ \\
\hline$S_{t} R$ & 6 & 337.97 & 349.97 & Time effect on $S$, constant $R$ \\
\hline$S R_{t}$ & 6 & 346.94 & 358.94 & Constant $S$, time effect on $R$ \\
\hline $\mathrm{S}_{\mathrm{s}} \mathrm{R}_{\mathrm{s}}$ & 4 & 355.23 & 363.23 & Sex differences in $S$ and $R$ \\
\hline $\mathrm{S}_{\mathrm{s}} \mathrm{R}$ & 3 & 355.24 & 361.24 & Sex differences in $S$, constant $R$ \\
\hline $\mathrm{S} \mathrm{R}_{\mathrm{s}}$ & 3 & 355.44 & 361.44 & Constant $S$, sex differences in $R$ \\
\hline S R & 2 & 355.51 & 359.51 & Constant $\mathrm{S}$ and $\mathrm{R}$ \\
\hline
\end{tabular}

${ }^{a} \mathrm{~S}=$ survival probability, $\mathrm{R}=$ recapture probability, $\mathrm{s}=\mathrm{sex}, \mathrm{t}=$ time, $\mathrm{st}=\mathrm{sex} \times$ time interaction

${ }^{\mathrm{b}} \mathrm{DEV}=$ model deviance. 
TABLE 3. Akaike's Information Criterion (AIC) scores for some models investigating annual survival and recapture rates using the program SURGE for adult male and juvenile Saltmarsh Sharp-tailed Sparrows in Rhode Island, 1993-1998.

\begin{tabular}{|c|c|c|c|c|}
\hline Model $^{\mathrm{a}}$ & $\begin{array}{c}\text { No. of } \\
\text { parameters }\end{array}$ & $\mathrm{DEV}^{\mathrm{b}}$ & AIC & Comparison \\
\hline$S_{3 t} R_{a t}$ & 20 & 564.09 & 600.09 & Age-time interaction on $S$ and $R$ \\
\hline$S_{a t} R_{a}^{a t}$ & 12 & 571.86 & 595.86 & Age-time interaction on $S$, age differences in $R$ \\
\hline$S_{a t} R_{t}$ & 15 & 567.01 & 595.01 & Age-time interaction on $\mathrm{S}$, time effect on $\mathrm{R}$ \\
\hline $\mathrm{S}_{\mathrm{at}} \mathrm{R}$ & 11 & 573.93 & 595.93 & Age-time interaction on $\mathrm{S}$, constant $\mathrm{R}$ \\
\hline$S_{a} R_{a t}$ & 12 & 588.95 & 612.95 & Age differences in $S$, age-time interaction on $R$ \\
\hline$S_{t} R_{a t}$ & 15 & 590.04 & 620.04 & Time effect on $\mathrm{S}$, age-time interaction on $\mathrm{R}$ \\
\hline$S R_{a t}$ & 11 & 610.95 & 632.95 & Constant $\mathrm{S}$, age-time interaction on $\mathrm{R}$ \\
\hline$S_{a} R_{t}$ & 7 & 604.82 & 618.82 & Age differences in $\mathrm{S}$, time effect on $\mathrm{R}$ \\
\hline$S_{t}^{a} R_{a}$ & 7 & 618.61 & 632.61 & Time effect on $S$, age differences in $R$ \\
\hline$S_{t} R_{t}$ & 10 & 637.67 & 655.67 & Time effect on $\mathrm{S}$ and $\mathrm{R}$ \\
\hline$S, R$ & 6 & 644.63 & 656.63 & Time effect on $S$, constant $R$ \\
\hline$S R_{t}$ & 6 & 647.07 & 659.07 & Constant $\mathrm{S}$, time effect on $\mathrm{R}$ \\
\hline $\mathrm{S}_{\mathrm{a}} \mathrm{R}_{\mathrm{a}}$ & 4 & 607.40 & 615.40 & Age differences in $\mathrm{S}$ and $\mathrm{R}$ \\
\hline$S_{a} R^{a}$ & 3 & 608.92 & 614.92 & Age differences in $S$, constant $R$ \\
\hline$S R_{a}$ & 3 & 629.61 & 635.61 & Constant $S$, age differences in $R$ \\
\hline S R & 2 & 652.58 & 656.58 & Constant $\mathrm{S}$ and $\mathrm{R}$ \\
\hline
\end{tabular}

a $\mathrm{S}=$ survival probability, $\mathrm{R}=$ recapture probability, $\mathrm{a}=$ age, $\mathrm{t}=$ time, at $=$ age $\times$ time interaction

${ }^{\mathrm{b}} \mathrm{DEV}=$ model deviance.

vs. model $\left.S_{t} R ; \chi^{2}=4.1, \mathrm{df}=5, P=0.54\right)$, but did exhibit significant annual variation (model $\mathrm{S}_{\mathrm{t}} \mathrm{R}$ vs. S R; $\left.\chi^{2}=17.5, \mathrm{df}=4, P=0.002\right)$.

Apparent survival rates of juveniles also varied annually and were significantly lower than adult survival rates. The best-fit model, $S_{\text {at }} R$, indicated a high constant recapture probability of $84.7 \%$ (95\% CI: 68.7-93.3\%), higher adult survival, annual variation in adult survival which declined from 1994 to 1997, and substantial annual variation in juvenile survival (Table 3 and Fig. 2). The mean apparent survival estimate of $39.6 \%$ (model $S_{a} R, 95 \%$ CI: $33.3-46.2 \%$ ) for birds first banded as adults during 1993-1998, was more than double the mean estimate of $14.4 \%$ (model S $\mathrm{R}, 95 \% \mathrm{CI}$ : $10.6-19.3 \%$ ) for those banded as juveniles. Individual likelihood-ratio tests confirmed apparent survival probabilities varied significantly between juveniles and adults (model $S_{a t} R$ vs. model $\left.S_{t} R ; \chi^{2}=70.7, \mathrm{df}=5, P<0.001\right)$ and showed significant annual variation (model $S_{a t}$ R vs. $S_{a} R ; \chi^{2}=35, \mathrm{df}=8, P<0.001$ ).

First-year apparent survival (hatching to second year, age class 1) was significantly lower than after-second-year apparent survival (second through fifth years, age class 2) of birds first captured as juveniles at Galilee (model $\mathrm{S}_{(2 \mathrm{a}) \mathrm{t}} \mathrm{R}$ vs. model $\mathrm{S}_{\mathrm{t}} \mathrm{R} ; \chi^{2}=20.3$, df $=4, P<$ 0.001). Mean apparent survival of juveniles from hatching to their second year was $11.4 \%$
(CI: $8.2-15.8 \%$ ) and increased to $23.7 \%$ (CI: $12.8-36.6 \%$ ) for after-second-year birds (means from model $S_{2 a} R$ ). Of returning juveniles, four males and three females were captured in three consecutive years and one male was captured in four consecutive years.

Return rates. - Cumulative return-rate estimates (Custer and Pitelka 1977) were 37.5\% (57/152) for male and 34.3\% (34/99) for female sparrows at Galilee (Table 4). Of sparrows banded during 1993 to 1997, 46.2\% (30/65) adult females, $46.3 \%$ adult males (44/95), and $11.4 \%$ juveniles $(31 / 271)$ returned during 1994 to 1998 . From 1994 to $1998,61 \%$ of returning juveniles (second-year birds) were male and $35 \%$ female ( $4 \%$ unknown sex).

Annual return rates during 1994 to 1998 at Galilee varied (adults: $\chi^{2}=18.62, \mathrm{df}=4, P=$ 0.001; juveniles: $\chi^{2}=32.53, \mathrm{df}=4, P<0.001$ ) and adults returned at significantly higher rates than juveniles during all years except $1997\left(\chi^{2}=2.30, \mathrm{df}=1, P=0.13\right)$. Adult return rates were highest in 1994 at $56.5 \%$, and then declined and leveled off to $23.4-35.1 \%$ during 1995 to 1998 (Fig. 3). Juvenile return rates varied from a low of $0 \%$ in 1996 and 1998 to a peak of $43.8 \%$ in 1997, with no visible trend (Fig. 3). Mean adult return rate of $35.1 \%$ was significantly higher (over three-fold) than the juvenile rate of $11.6 \%\left(\chi^{2}=45.08, \mathrm{df}=1, P<0.001\right)$. Return rates of male and female adults were 
TABLE 4. Cumulative number of Saltmarsh Sharptailed Sparrows returning to Galilee Marsh from 1993 through 1998 at Galilee Marsh, Rhode Island. Total number of birds banded each year is shown in New column. Based on methods from Custer and Pitelka (1977).

\begin{tabular}{|c|c|c|c|c|c|c|}
\hline \multirow[b]{2}{*}{ Year } & \multirow{2}{*}{$\frac{\mathrm{New}^{\mathrm{a}}}{1}$} & \multicolumn{5}{|c|}{ Year of return } \\
\hline & & 2 & 3 & 4 & 5 & 6 \\
\hline \multicolumn{7}{|l|}{ MALE } \\
\hline 1933 & 40 & 23 & 9 & 5 & 2 & 0 \\
\hline 1994 & 19 & 5 & 1 & 1 & 1 & \\
\hline 1995 & 8 & 2 & 0 & 0 & & \\
\hline 1996 & 13 & 3 & 0 & & & \\
\hline 1997 & 15 & 5 & & & & \\
\hline Total & 95 & 38 & 10 & 6 & 3 & 0 \\
\hline \multicolumn{7}{|l|}{ FEMALE } \\
\hline 1993 & 29 & 16 & 4 & 2 & 0 & 0 \\
\hline 1994 & 20 & 5 & 1 & 1 & 1 & \\
\hline 1995 & 4 & 0 & 0 & 0 & & \\
\hline 1996 & 4 & 0 & 0 & & & \\
\hline 1997 & 8 & 4 & & & & \\
\hline Total & 65 & 25 & 5 & 3 & 1 & 0 \\
\hline
\end{tabular}

${ }^{\mathrm{a}} \mathrm{New}=$ first capture. not significantly different during any year with mean returns of 37.6 and $35.6 \%$, respectively $\left(\chi^{2}=0.12, \mathrm{df}=1, P=0.73\right)$.

At all 10 study sites, adults returned at a higher rate than juveniles and in 1997, adult males returned at a higher rate than females. In addition to the 79 sparrows banded at Galilee in 1996 and 1997, we banded an additional 404 birds at the 9 satellite marshes. A total of 223 adult males, 115 adult females, 19 adults of unknown sex, and 126 juveniles were banded during 1996 to 1997 at all study marshes. Adult return rates at Galilee and satellite marshes, which ranged from 22.2 to $47.1 \%$, were not different among the four sites in $1997\left(\chi^{2}=3.42\right.$, $\mathrm{df}=3, P=0.33)$ and all 10 sites in $1998\left(\chi^{2}=\right.$ $6.85, \mathrm{df}=7, P=0.45$; Fig. 4). In 1997, mean return rate of $40 \%$ by males was significantly different from mean rate of $13.3 \%$ for females $\left(\chi^{2}=7.59, \mathrm{df}=1, P=0.006\right)$, whereas in 1998 , male return rates $(31 \%)$ were not significantly different from females $(35.2 \%)\left(\chi^{2}=0.58, \mathrm{df}=\right.$ $1, P=0.446)$. Juvenile return rates, however, did vary significantly among study sites in

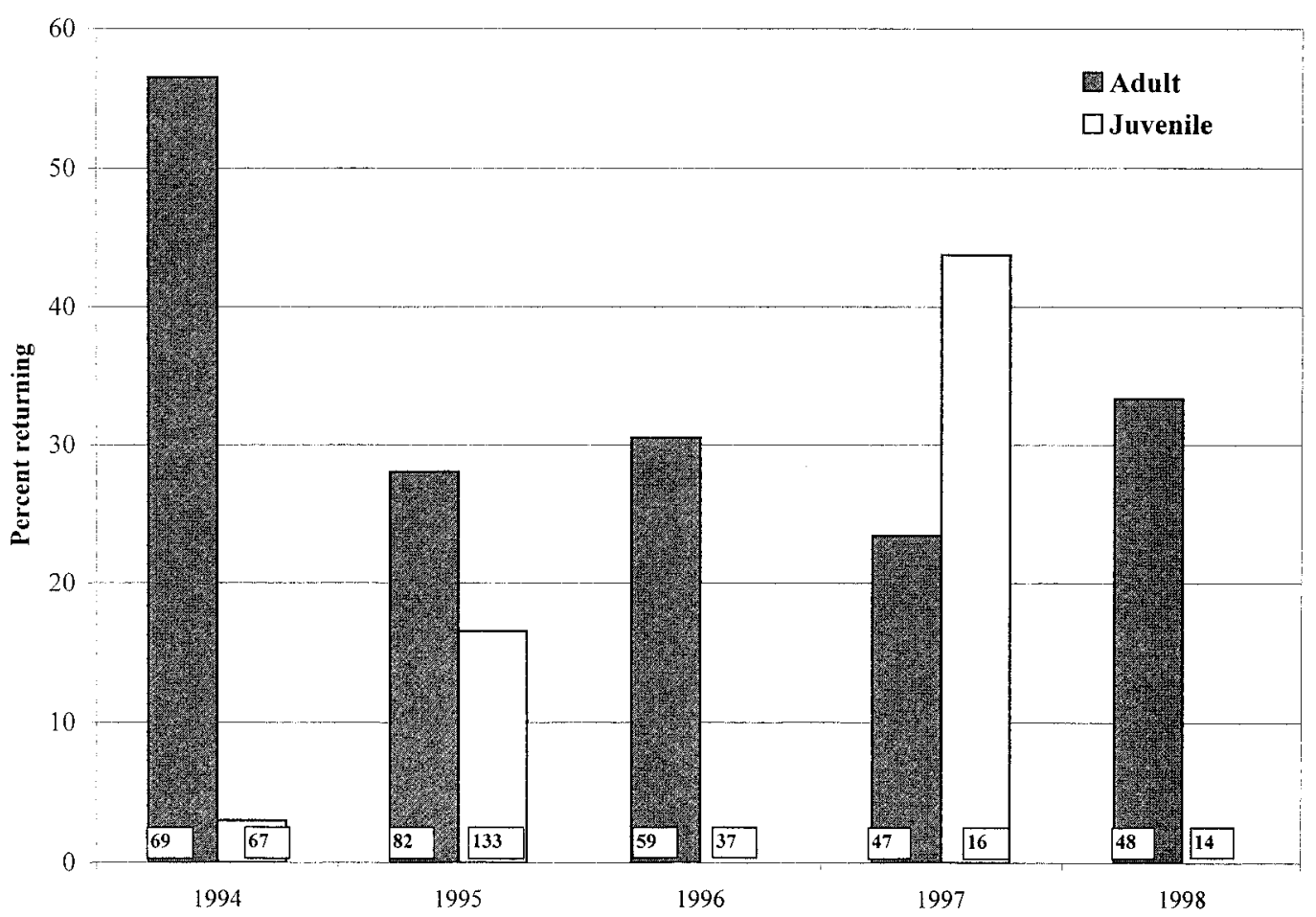

FIG. 3. Annual return rates of adult and juvenile Saltmarsh Sharp-tailed Sparrows at Galilee Marsh during 1993-1998. Number of sparrows present during year one, that were available to (survive and) return in year two, appears at base of bars. 

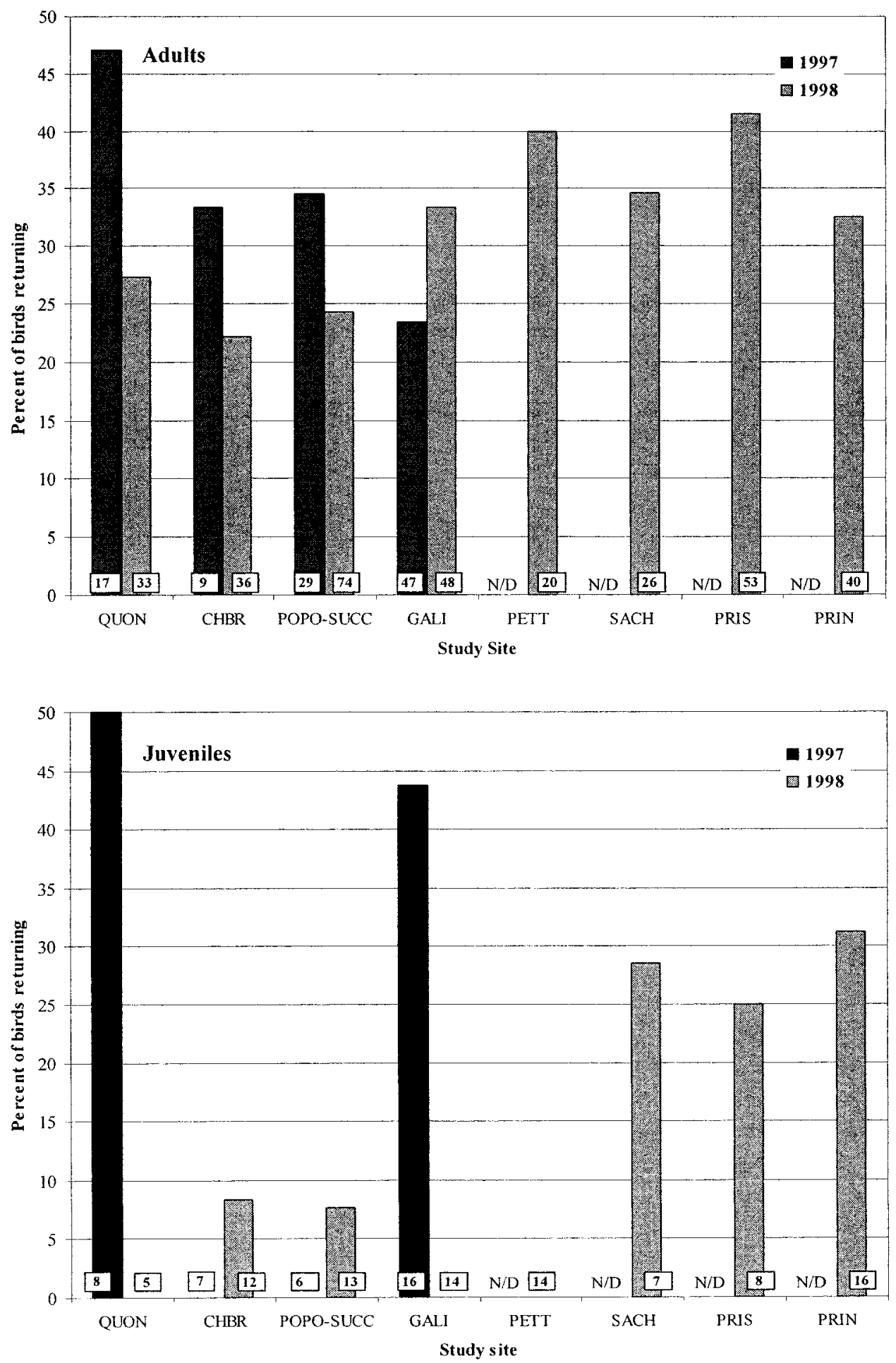

FIG. 4. Annual return rates for adult and juvenile Saltmarsh Sharp-tailed Sparrows at all study sites in southern Rhode Island during 1996-1998. Number of sparrows present during year one, that are available to survive and return in year two, appears at base of bars. N/D = no data. See Figure 1 for site abbreviations. 
TABLE 5. Number of banded Saltmarsh Sharp-tailed Sparrows moving among mainland and island marshes in Rhode Island, 1996-1998. NACR-E = Nag Creek-East, NACR-W = Nag Creek-West, COGG = Coggeshall, and NOEN = North End. See Figure 1 for mainland site abbreviations.

\begin{tabular}{|c|c|c|c|c|c|c|}
\hline \multirow{2}{*}{$\frac{\text { Banding marsh }}{\text { QUON }}$} & \multicolumn{6}{|c|}{ Resighting marsh } \\
\hline & QUON & & & & & \\
\hline$\widehat{C} \mathrm{HBR}$ & 1 & CHBR & & & & \\
\hline POPO & 0 & 0 & POPO & & & \\
\hline SUCC & 1 & 0 & 7 & SUCC & & \\
\hline GALI & 1 & 1 & 5 & 3 & GALI & \\
\hline PETT & 0 & 0 & 1 & 1 & 2 & PETT \\
\hline $\mathrm{SACH}$ & 0 & 0 & 1 & 0 & 1 & 0 \\
\hline \multicolumn{7}{|c|}{ Prudence Island } \\
\hline NACR-E & NACR-E & & & & & \\
\hline NACR-W & 17 & NACR-W & & & & \\
\hline COGG & 0 & 1 & COGG & & & \\
\hline NOEN & 1 & 3 & 6 & & & \\
\hline
\end{tabular}

$1997\left(\chi^{2}=12.01, \mathrm{df}=3, P=0.002\right)$ and in 1998 $\left(\chi^{2}=15.39, \mathrm{df}=7, P=0.03\right.$, ranging from 0 to $50 \%$ during both years. At all study sites during 1996 to $1998,65 \%$ of the returning juveniles were males and $26 \%$ were females. Mean return rates of $31.4 \%$ for adults and $29.7 \%$ for juveniles were not significantly different in $1997\left(\chi^{2}=\right.$ $0.03, \mathrm{df}=1, P=0.85)$, but return rates of $31.2 \%$ for adults and $12.4 \%$ for juveniles were significantly different in $1998\left(\chi^{2}=14.20, \mathrm{df}=1, P\right.$ $=0.001$ ).

Local movement.-Forty-nine of 483 (10.1\%) sparrows banded during 1996 and 1997 moved among study sites during 1996-1998 (Table 5). We documented movements by 39 adult males, 5 adult females, and 5 juveniles. Within-year movements were made by 29 birds, betweenyear movements by 14 birds, and six individuals moved both within and between years. Most individuals moved once, 10 (9 males and 1 female) moved twice, and one male moved three times. Most birds moved between two study marshes; however, one female and one male moved among three marshes. Movement was greatest between adjacent marshes separated by short distances or barriers (i.e. roads): Potter's Pond and Succotash $(0.4 \mathrm{~km})$, Nag Creek marshes (East and West, $0.4 \mathrm{~km}$ ), and Coggeshall and the North End $(1.2 \mathrm{~km})$ (Table 5). Five individuals moved between the north and south complexes on Prudence Island (3.5$5.8 \mathrm{~km})$, but none traveled between Prudence Island and mainland sites (16.4-21.9 km to closest sites). The longest dispersal events occurred between Potter's Pond and Sachuest $(26.4 \mathrm{~km})$, and Galilee and Sachuest $(24.3 \mathrm{~km})$.

\section{DISCUSSION}

Little empirical information exists on dispersal patterns and survival rates of promiscuous passerines, that is, species that mate indiscriminately with no pair bond (Greenwood 1980, Liberg and von Schantz 1985, Clarke et al. 1997). Avian dispersal theory is based primarily on studies of behaviorally monogamous species because over $90 \%$ of birds exhibit that mating system (Lack 1968, Greenwood 1980, Clarke et al. 1997). Adult male Saltmarsh Sharp-tailed Sparrows apparently survived at similar rates to adult females despite emancipation from parental and resource defense duties in a promiscuous mating system. The observed pattern of similar male and female survival, and greater adult versus juvenile survival, occurs regularly among passerines possessing a variety of mating systems (Dyer et al. 1977, Wittenberger 1978, Searcy and Yasukaw 1981, Post and Greenlaw 1982, Bollinger and Gavin 1989, Murphy 1996, Chase et al. 1997).

In Rhode Island, Saltmarsh Sharp-tailed Sparrows exhibited moderate breeding-site fidelity, with no statistically significant genderbias and strong natal philopatry. Juvenile Saltmarsh Sharp-tailed Sparrow return rates, averaging $11.6-29.7 \%$, were high for a passerine (reviewed in Weatherhead and Forbes 1994) and greater than juvenile sparrows in New York, which returned to their natal marsh at a rate of $6.7-7.0 \%$ the following year (Greenlaw and Rising 1994). The return of twice as many male juveniles in Rhode Island may suggest a gender-bias in natal dispersal; however, Salt- 
marsh Sharp-tailed Sparrows typically exhibit a 2:1 gender ratio at breeding sites (Montagna 1942, Woolfenden 1956, Post 1970, Greenlaw and Rising 1994). Post and Greenlaw (1982) also found no significant difference in cumulative return rates of adult male (54.7-60.3\%) and adult female (53.0-63.6\%) sparrows in New York. Their cumulative return rates indicated even stronger site fidelity than comparable estimates in Rhode Island (males 37.5\%, females $34.3 \%$ ).

Greenwood (1980) concluded that a genderbias in dispersal is promoted by reproductive enhancement afforded through increased access to mates or resources and avoidance of inbreeding, whereas the direction of bias is a consequence of mating system. According to Greenwood's theory (1980), unbiased dispersal is promoted when males and females do not differentially acquire reproductive benefits through dispersal. Site fidelity patterns of juvenile Saltmarsh Sharp-tailed Sparrows and other promiscuous and polygamous species (Marks and Redmond 1987, Reynolds and Cooke 1988, Russell and Rowley 1993) contradict the hypothesis that reproductive competition between juveniles and parents in promiscuous birds leads to equally high dispersal rates by male and female young (Liberg and von Schantz 1985).

Inconsistent results from studies of polygamous birds suggest that mating system may not be the most influential factor on dispersal. Non-gender-biased breeding dispersal has been documented for passerines of various mating systems including promiscuous, cooperative, and monogamous (Woolfenden and Fitzpatrick 1984, Arcese 1989, Russell and Rowley 1993, Norment 1994, Regosin and Pruett-Jones 1995, Clarke et al. 1997). Clarke et al. (1997) documented female-biased dispersal in $53 \%$ of 55 species studied, male-biased dispersal in $15 \%$, and no gender bias in 33\%. Male and nonbiased dispersal occurred across various mating systems, including monogamous, polygynous, and communal. Evidence of unbiased and female-biased dispersal varies among polygamous birds (Arcese 1989, Bollinger and Gavin 1989, Payne and Payne 1993, Yasukawa and Searcy 1995, Clarke et al. 1997, Wheelwright and Mauck 1998).

Moderate breeding-site fidelity by Saltmarsh Sharp-tailed Sparrows may be influenced by the availability of high-quality salt marsh habitat in the Northeast, rather than by their promiscuous mating system or previous nest success (DiQuinzio 1999). Females must choose habitats and nest sites of sufficient quality to provide them with resources to successfully rear offspring alone and maintain lifetime fitness (Post and Greenlaw 1982). They face the costly risk of selecting a low-quality nest site by dispersing among naturally discontinuous, often human-altered salt marshes (Reinert et al. 1981, Tiner 1984, Rozsa 1995). Greenlaw and Rising (1994) concluded that dispersal of nesting female sparrows is influenced by patchiness of available breeding microhabitat. With no parental or resource-defense duties, access to females should be the primary determinant of male reproductive success and thus dispersal. The positive effect of female movements on male dispersal was demonstrated by removal experiments with promiscuous Splendid Fairywrens (Malurus splendens; Pruett-Jones and Lewis 1990). Moderate movement of male sparrows among study marshes in Rhode Island during the breeding season suggests they have greater mobility in foraging and seeking females.

Survival and reproductive benefits afforded through familiarity and prior experience of quality habitats have been demonstrated to promote site fidelity in many birds, including those in promiscuous and other polygamous mating systems (Jamieson and Zwickel 1983, Bollinger and Gavin 1989, Bensch and Hasselquist 1991, Ligon et al. 1991, Montalvo and Potti 1992). Dispersal of female sparrows may be primarily influenced by familiarity and previous experience with available habitat (Reynolds and Cooke 1988, Pärt and Gustafsson 1989, Bensch and Hasselquist 1991). Male dispersal may be influenced by their prior experience with female abundance and availability (Reynolds and Cooke 1988, Wheelwright and Mauck 1998). Familiarity with other resources of the home range may influence male dispersal directly through fitness benefits or indirectly by facilitating access to females.

Some researchers hypothesize that migratory juveniles automatically incur dispersal costs, unlike resident birds, and benefit little by returning to the natal area, unless suitable breeding habitat is restricted (Weatherhead and Boak 1986, Weatherhead and Forbes 1994). Weather- 
head and Forbes (1994) found natal philopatry was significantly higher in resident (range: 039.7 , median $=6.3, n=11$ ) versus migratory populations $(0-13.5$, median $=2.6, n=35)$. They found most migratory species that exhibited high juvenile returns were from isolated populations. In our study, mean juvenile sparrow return rates at all marshes in 1997 (29.7\%) and in 1998 (12.4\%), and at Galilee from 1993 to $1998(11.6 \%)$ fall at the upper end of documented return rates for migrants and well within typical return rates for residents. Philopatry to restricted and isolated breeding marshes suggests that juvenile sparrows may also benefit from site familiarity acquired during brooding and fledging periods.

Site fidelity of Saltmarsh Sharp-tailed Sparrows may be related to discontinuous distribution of salt-marsh habitat with suitable resources. Ninety-percent of their breeding range occurs in the Northeast, where many salt marshes have been ditched, impounded, and isolated by urbanization (Bourn and Cottam 1950, Tiner 1984, Rozsa 1995). Degradation and significant reduction of suitable breeding habitat has resulted in decreased abundance and localized extirpation of Saltmarsh Sharp-tailed Sparrows (Reinert et al. 1981, Greenlaw and Rising 1994, Benoit and Askins 1999). In response to widespread loss of habitat quality and quantity, efforts to restore salt marshes are increasing throughout the Northeast. Our study indicates that Saltmarsh Sharp-tailed Sparrows can be highly site-faithful to a particular marsh, but also readily disperse among marshes. If remaining high-quality habitat is maintained to ensure population viability, our results suggest sparrows will rapidly recolonize degraded marshes that are restored.

\section{ACKNOWLEDGMENTS}

We thank Karen Ambrose, Warren Conway, Norman Davis, Andy Deegan, Dana Filipinni, Andy Forbes, Corey Grinnell, Andrea LePard, Kim Henderson, Brian Harrington, Robin Krebs, Dierdre Robinson, and Colin Studds for their assistance in collecting field data. We thank the Rhode Island Department of Environmental Management, Rhode Island Division of Fish and Wildlife, U.S. Department of the Interior, Fish and Wildlife Service, and Narragansett Bay Estuarine Research Reserve for access to land. We thank Frank Golet and Dennis Myshrall for all the support they have provided this project. This manuscript was improved by comments by F. C. Golet, C. Roman, S. Twombly, and two anonymous reviewers. This research was supported by grants from the University of Rhode Island Coastal Fellowship Program, RI DEM Federal Aid to Wildlife Restoration, and National Oceanic and Atmospheric Association. This is contribution no. 3893 of the Rhode Island Agricultural Experiment Station.

\section{Literature Cited}

ARCESE, P. 1989. Intrasexual competition, mating system and natal dispersal in Song Sparrows. Animal Behaviour 38:958-979.

August, P. V., A. McCann, And C. LaBash. 1995. GIS in Rhode Island. Rhode Island Cooperative Extension Fact Sheet 95-1:1-12.

BENOIT, L. K., AND R. A. AsKINS. 1999. Impact of the spread of Phragmites on the distribution of birds in Connecticut tidal marshes. Wetlands 19:194208.

Bensch, S., AND D. Hasselquist. 1991. Territory infidelity in the polygynous Great Reed Warbler Acrocephalus arundinaceus: The effect of variation in territory attractiveness. Journal of Animal Ecology 60:857-871.

Bertness, M. D. 1992. The ecology of a New England salt marsh. American Scientist 80:260-269.

Bollinger, E. K., AND T. A. GAVIN. 1989. The effects of site quality on breeding-site fidelity in Bobolinks. Auk 106:584-594.

BOURN, W. S., AND C. CotTAM. 1950. Some biological effects of ditching tidewater marshes. Research Report 19, U.S. Department of the Interior, Fish and Wildlife Service, Washington, D.C.

Burnham, K. P., D. R. Anderson, G. C. White, C. Brownie, AND K. H. Pollock. 1987. Design and analysis methods for fish survival experiments based on release-recapture. American Fisheries Society Monographs, no. 5.

Chase, M. K., N. Nur, AND G. R. Geupel. 1997. Survival, productivity, and abundance in a Wilson's Warbler population. Auk 114:354-366.

Clarke, A. L., B. E. SÆTHer, AND E. Roskaft. 1997. Sex biases in avian dispersal: A reappraisal. Oikos 79:429-438.

Cooch, E. G., R. Pradel, AND N. Nur. 1996. A Practical Guide to Mark-Recapture Analysis Using SURGE. Centre d'Ecologie Fonctionelle et Evolutive-CNRS, Montpellier, France.

Custer, T. W., AND F. A. PitelKa. 1977. Demographic features of a Lapland Longspur population near Barrow, Alaska. Auk 94:505-525.

DeRAgON, W. R. 1988. Breeding ecology of Seaside and Sharp-tailed sparrows in Rhode Island salt marshes. M.S. thesis, University of Rhode Island, Kingston.

DiQuinZIO, D. A. 1999. Population and breeding ecology of the promiscuous Saltmarsh Sharptailed Sparrow in Rhode Island salt marshes. 
M.S. thesis, University of Rhode Island, Kingston.

Dyer, M. I., J. PINOWSKI, ANd B. PinOwsKa. 1977. Population dynamics. Pages 53-105 in Granivorous Birds in Ecosystems (J. Pinowski and S. C. Kendeigh, Eds.). Cambridge University Press, Cambridge, United Kingdom.

EHrLich, P. R., D. S. DobKIN, AND D. WheYe. 1988. The Birder's Handbook: A Field Guide to the Natural History of North American Birds. Simon and Schuster, New York.

ENVIRONMENTAL SYSTEMS RESEARCH InSTITUTE. 1998. What's New in ArcView GIS, version 3.1. ESRI, Inc., Redlands, California.

GREenLAW, J. S., AND J. D. RIsING. 1994. Sharp-tailed Sparrow (Ammodramus caudacutus). In The Birds of North America, no. 112 (A. Poole and F. Gill, Eds.). Academy of Natural Sciences, Philadephia, and American Ornithologists' Union, Washington, D.C.

GREENWOOD, P. J. 1980. Mating systems, philopatry and dispersal in birds and mammals. Animal Behaviour 28:1140-1162.

JAMIESON, I. G., AND F. C. ZWICKEL. 1983. Dispersal and site fidelity in Blue Grouse. Canadian Journal of Zoology 61:570-573.

JOLLY, G. M. 1965. Explicit estimates from capturerecapture data with both death and immigration-stochastic models. Biometrika 52:225-247.

LACK, D. 1968. Ecological Adaptations for Breeding in Birds. Methuen, London.

Lebreton, J.-D., K. P. Burnham, J. Clobert, And D. R. ANDERSON. 1992. Modeling survival and testing biological hypotheses using marked animals: A unified approach with case studies. Ecological Monographs 62:67-118.

LiberG, O., AND T. V. SCHANTZ. 1985. Sex-biased philopatry and dispersal in birds and mammals: The Oedipus hypothesis. American Naturalist 126: 129-135.

Ligon, J. D., S. H. Ligon, AND H. A. Ford. 1991. An experimental study of the bases of male philopatry in the cooperatively breeding Superb Fairy-Wren Malurus cyaneus. Ethology 87:134148.

Loery, G., J. D. Nichols, AND J. E. Hines 1997. Capture-recapture analysis of a wintering Blackcapped Chickadee population in Connecticut, 1958-1993. Auk 114:431-442.

MARKS, J. S., AND R. L. REDMOND. 1987. Parent-offspring conflict and natal dispersal in birds and mammals: Comments on The Oedipus Hypothesis. American Naturalist 129:158-164.

MontAGNA, W. 1942. The Sharp-tailed Sparrows of the Atlantic Coast. Wilson Bulletin 54:107-120.

Montalvo, S., AND J. PotTI. 1992. Breeding dispersal in Spanish Pied Flycatchers Ficedula hypoleuca. Ornis Scandinavica 23:491-498.
MuRPHY, M. T. 1996. Survivorship, breeding dispersal and mate fidelity in Eastern Kingbirds. Condor 98:82-92.

Norment, C. J. 1994. Breeding site fidelity in Harris's Sparrows, Zonotrichia querula, in the Northwest Territories. Canadian Field-Naturalist 108:234236.

ORING, L. W., AND R. D. SAYler. 1992. The mating systems of waterfowl. Pages 190-213 in Ecology and Management of Breeding Waterfowl (B. D. J. Batt, A. D. Afton, M. G Anderson, C. D. Ankney, D. H. Johnson, J. A. Kadlec, and G. L. Krapu, Eds.). University of Minnesota Press, Minneapolis.

PÄRT, T., AND L. Gustafsson. 1989. Breeding dispersal in the Collared Flycatcher (Ficedula albicollis): Possible causes and reproductive consequences. Journal of Animal Ecology 58:305-320.

Payne, R. B., And L. L. Payne. 1993. Breeding dispersal in Indigo Buntings: Circumstances and consequences for breeding success and population structure. Condor 95:1-24.

Post, W. 1970. Ditched salt marsh. Audubon Field Notes 24:772-773.

Post, W., AND J. S. GReEnlaw. 1982. Comparative costs of promiscuity and monogamy: A test of reproductive effort theory. Behavioral Ecology and Sociobiology 10:101-107.

Pradel, R., J. E. Hines, J.-D. Lebreton, and J. D. NichOLS 1997. Capture-recapture survival models taking account of transients. Biometrics 53:60-72.

Pruett-Jones, S. G., AND M. J. Lewis. 1990. Sex ratio and habitat limitation promote delayed dispersal in Superb Fairy-Wrens. Nature 348:541-542.

PYlE, P. 1997. Identification Guide to North American Passerines. Slate Creek Press, Bolinas, California.

Regosin, J. V., And S. Pruett-Jones. 1995. Aspects of breeding biology and social organization in the Scissor-tailed Flycatcher. Condor 97:154-164.

Reinert, S., E. F. C. Golet, AND W. R. DeRagon. 1981. Avian use of ditched and unditched salt marshes in southeastern New England: A preliminary report. Proceedings of the Northeast Mosquito Control Association, Newport, Rhode Island.

ReYNOLDS, J. D., AND F. COOKE. 1988. The influence of mating systems on philopatry: A test with polyandrous Red-necked Phalaropes. Animal Behaviour 36:1788-1795.

RozsA, R. 1995. Human impacts on tidal wetlands: History and regulations. Pages 42-50 in Tidal Marshes of Long Island Sound: Ecology, History and Restoration (G. D. Dreyer and W. A. Niering, Eds.). Connecticut College Arboretum Bulletin no. 34, New London.

Russell, E. M., AND I. Rowley. 1993. Philopatry or dispersal: Competition for territory vacancies in 
the Splendid Fairy-wren, Malurus splendens. Animal Behaviour 45:519-539.

SAS INSTITUTE. 1988. SAS/STAT User's Guide, version 6.03. SAS Institute Inc., Cary, North Carolina.

SEARCy, W. A., AND K. YasukaW. 1981. Sexual size dimorphism and survival of male and female blackbirds (Icteridae). Auk 98:457-465.

Seber, G. A. F. 1965. A note on the multiple recapture census. Biometrika 52:249-259.

Sibley, D. 1996. Field identification of the Sharptailed Sparrow complex. Birding 28:197-208.

TINER, R. W., JR. 1984. Wetlands of the United States: Current status and recent trends. U.S. Fish and Wildlife Service, National Wetlands Inventory, Washington, D.C.

Weatherhead, P. J., AND K. A. BoAK. 1986. Site infidelity in Song Sparrows. Animal Behaviour 34: 1299-1310.

WeAtherhead, P. J., AND M. R. L. Forbes. 1994. Natal philopatry in passerine birds: Genetic or ecological influences? Behavioral Ecology 5:426433.
Wheelwright, N. T., AND R. A. Mauck. 1998. Philopatry, natal dispersal, and inbreeding avoidance in an island population of Savannah Sparrows. Ecology 79:755-767.

WitTENBERGER, J. F. 1978. The breeding biology of an isolated Bobolink population in Oregon. Condor 80:355-371.

WOOLFENDEN, G. E. 1956. Comparative breeding behavior of Ammospiza caudacuta and A. maritima. University of Kansas Publications, Museum of Natural History 10:45-75.

Woolfenden, G. E., AND J. W. FitzPatrick. 1984. The Florida Scrub Jay: Demography of a Cooperatively Breeding Bird. Princeton University Press, Princeton, New Jersey.

YASUKAWA, K., AND W. A. SEARCY. 1995. Redwinged Blackbird (Agelaius phoeniceus). In The Birds of North America, no. 184 (A. Poole and F. Gill, Eds.). Academy of Natural Sciences, Philadelphia, and American Ornithologists' Union, Washington, D.C.

Associate Editor: J. Brawn 